\title{
THE IMPLEMENTATION OF THE RULE OF THE MINISTRY OF RELIGIOUS AFFAIRS \#9 YEAR 2015 ON THE MANAGEMENT OF HAJJ IN MOJOKERTO DISTRICT
}

\author{
Hadianto Nuh Krama*, Gani Abdul Juli Andi, Hanafi Imam \\ Master's Program in Public Administration, Faculty of Administrative Science, \\ University of Brawijaya, Indonesia \\ *E-mail: hadinuh@yahoo.com
}

\begin{abstract}
Long waiting lists of Hajj does not decrease people's enthusiasm to fulfill the fifth obligation as moslem that is Hajj. Therefore, Hajj agencies should always provide excellent Hajj service. Excellent service should start by providing good implementation of the process of enrollment, implementation, and the closing. Well-prepared and well-implemented Hajj program prevents Hajj applicants from unexpected problems. The Hajj program should be professionally handled from the enrollment process. This study attempts at reviewing the implementation of the rule issued by the Ministry of Religious Affairs Number 9 Year 2015 about the implementation of Hajj program in Mojokerto District in optimizing Hajj service and providing easiness for Hajj applicants during the process that support Hajj applicants to become more independent. This program is the realization of the current laws issued by the Ministry of Religious Affairs in Indonesia. The main focus of this study is the implementation of the policy issued by the Ministry of Religious Affairs on the implementation of public service and its impact to Hajj applicants. This study employed an interactive research method and descriptive qualitative approach which intended to 1) describe the implementation of the Rule of the Ministry of Religious Affairs Number 29 Year 2015 about the implementation of Hajj program in Mojokerto district, 2) analyze the efforts made by Hajj agencies in improving Hajj service in Mojokerto district. The result of this study shows that the implementation of Hajj program in Mojokerto district has been optimally administered. Yet, it is necessary to improve the facilities that support the Hajj program to create transparent service and provide accessible information about the Hajj program. Moreover, in this modern era, public demands effective and efficient Hajj service. Besides, the massive use of social media should support the government in socializing any information about Hajj and enhance the quality of Hajj service in Mojokerto district.
\end{abstract}

\section{KEY WORDS}

Implementation, Hajj program, public service.

The law number 13 year 2008 states the guideline of the implementation of Hajj program in which the government set certain standards that should be applied by Hajj agencies including the consultation, service and protection for Hajj applicants. This program is intended to provide good preparation, service and protection for Hajj applicants in conducting their Hajj obligation, allowing them to focus on their Hajj obligation as moslem. However, the real implementation of the law number 13 year 2008 cannot yet fulfill public's expectation and demands. Hence, a recommendation to modify or change the rule number 13 year 2008 about the Hajj management to be the Rule of the Ministry of Religious Affairs number 25 year 2014 about the funding of regular Hajj program has appeared. Regarding to the problems that appeared during the Hajj process, the government through the Ministry of Religious Affairs has made some enhancement on the Rule of the Ministry of Religious Affairs Number 25 year 2014 and shifted it to the Rule of the Ministry of Religious Affairs number 29 Year 2015.

The long waiting list does not demotivate people in Mojokerto in administering the fifth obligation as moslem. The increasing number of Hajj applicants in every year causes the waiting lists become longer. Moreover, as stated by Drs. HM. Sakur, M.Si (the head of Hajj program of the Ministry of Religious Affairs in East Java) in the socialization of Hajj in Hotel 
Puncak Ayanna, Trawas-Mojokerto on the $9^{\text {th }}-11^{\text {th }}$ of Februrary 2016, the waiting list of Hajj in East Java has reached 22 year of waiting. It shows that if a Hajj applicant applies for Hajj in 2016, she/he will be able to administer the Hajj in 2038. Another problem appeared as the result of recklessness done by Hajj agencies which caused 3 elder Hajj applicants passed away during the Hajj program due to chronical diseases which triggers a question directed at the credibility of the Hajj applicants' health selection team. Meanwhile, the term istita'ah refers to the Hajj condition which requires Hajj applicants to have good state of physical and mental health.

Those problems have triggered various responses to seek for the solutions. In addition, problems that occurred among the public need to be solved through the implementation of effective policies. However, the policies applied by the government cannot simply solve all of the problems. Therefore, the policies should be adjusted to the kinds and the characteristics of the problems. Those problems during the Hajj program also have created some policies to solve them. Changes and modification have been applied to certain policies for the policies were considered unable to solve the problems. Edwards in Winarno (2012, p.177) stated that studies on the implementation of certain policies are necessary to conduct for the betterment of public administration and public policy. The implementation of certain policies is one of the steps in administering public policy including the planning of the policies and the consequences of the policies toward the public.

\section{LITERATURE REVIEW}

The Implementation Model of George Edward III. According to Edwards in Winarno (2012, p.177) studies on the implementation of public policies are crucial for the betterment of public administration and public policy. The implementation of public policies is a step in the realization of the public policies which also includes the planning of the policies and the consequences of the policies to the public. If a public policy is unable to solve or decrease certain targeted problem, it implies that the policy is a failure even if the policy was wellimplemented. On the other hand, a well-planned policy might also fail if the policy is not wellimplemented.

In reviewing the implementation of public policies, Edwards in Winarno (2012, p.177) proposed two questions; what are the conditions needed to get a policy successfully implemented? And what are the obstacles that make a policy fail? Edwards tried to answer these questions by analyzing for factors or crucial variables of the implementation of public policies. The factors or the variables are communication, resources, disposition, and bureaucratic structure.

Within the context of the analysis of the Hajj program implementation, the implementation started from the abstract condition related to the fulfillment of the success factors of a public policy implementation as proposed by George C. Edwards including the communication, resources, disposition and bureaucratic structure.

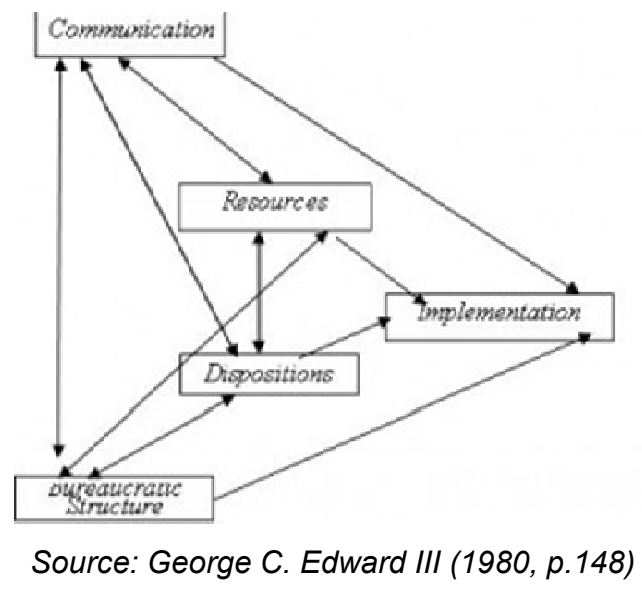

Figure 1 - Direct and Indirect Impact of Implementation Edward III 
Hajj Management as a Public Service. Basically, the implementation and the management of Hajj program is a public service which includes three kinds of services including; the consultation and Hajj Manasik before and after the Hajj, transportation, accommodation, catering and health services. As a public service, Hajj management should be held upon some principles; public interest, law certainty, equality, equity, professionalism, participation, non-discrimination, transparency, accountability, facility and special service for those with special needs, time efficiency, effectiveness, easiness, and accessibility. In addition, Hajj management should also consider the rights of Hajj applicants as stated in the law of consumer protection.

\section{METHODS OF RESEARCH}

This study employed an interactive method and descriptive qualitative approach. The focuses of this study included; 1) the implementation of Hajj program held by the branch of the Ministry of Religious Affairs in Mojokerto, especially related to the communication maintained among the Hajj officers, resources, disposition, and bureaucracy structure of the Hajj committee. 2) Government's role in improving the quality of Hajj service in the branch office of the Ministry of Religious Affairs in Mojokerto district.

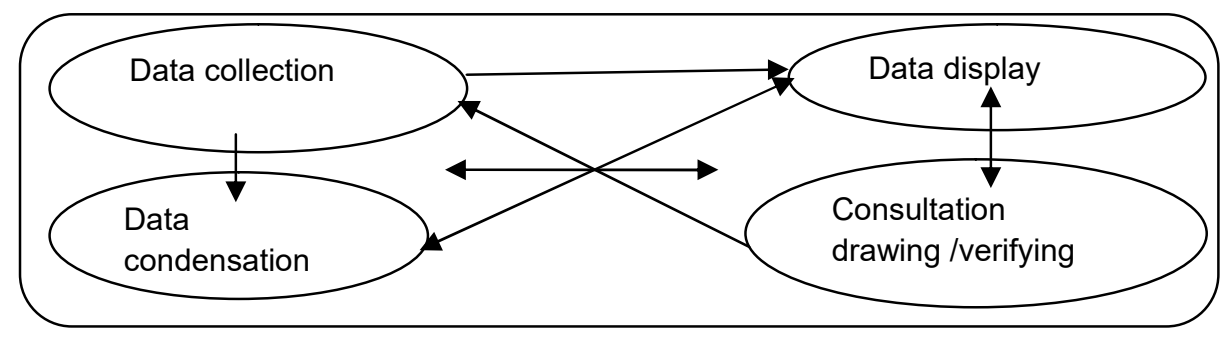

Source: Miles, Huberman dan Saldana (2014: 14)

Figure 2 - The Components of Data Analysis: An Interactive Model

This study was held in the Ministry of Religious Affair office in Mojokerto. The data of this study were obtained from informants, events and documents. The data were collected through interviews, observations, and document analysis. Furthermore, in analyzing the data of this study, the researcher referred to the theory proposed by Miles and Hubberman and Saldana, (2014: 14). This following figure shows the scheme of the data analysis proposed by Miles and Hubberman and Saldana (2014:14).

\section{RESULTS AND DISCUSSION}

Description on the Implementation of the Rule of Ministry of Religious Affairs Number 29 Year 2015 about Hajj Management in Mojokerto District. One of some points applied within the rule number 29 year 2015 is that Indonesian Hajj applicants should be at least 12 years old. In addition, for Hajj applicants who have done Hajj previously are allowed to enroll for another Hajj after 10 years started from the last Hajj. The use of the Hajj quota as stated in the article 1 refers to the applicants with following criteria: applicants who experienced system failure in paying the fund, applicants who have conducted Hajj previously are included in the remaining quota, applicants who are older than 75 years old are prioritized, the merge of families (heirs/wife) should be proven by legal marriage book and family card, the merge of mahram (heirs/parents) should be proven by the birth certificate, additional applicants who have fully paid the fund and the next year Hajj applicants.

Communication within the Implementation of Hajj Program Management in Mojokerto District. Communication is organizational events or activities that connects individuals, individuals and groups, and between organization and the surroundings. Communication has a major function in an organization, even communication is the factor that supports 
organizational administration, especially in managing the human resources. According to Elbert in Handayaningrat (1992, p.95), Communication may be defined as the transfer of information from one person to another signs, signals, or synables from a mutually understood language system. Within the context of communication in the Ministry of Religious Affairs office in Mojokerto, intensive communication has been enhanced to communicate and socialize the policies about Hajj management number 29 year 2015 to all of the staffs in order to enhance the Hajj service as expected by the rule.

Particularly, intern communication should be maintained based on the main jobs and functions in order to perform good implementation of a policy as stated by Effendy which goes in line with Edwards (Widodo, 2012, p.97) in which communication is seen as a process of delivering certain information of a communicator to a communicant. In this context, communication refers to the delivery of message related to certain policies or programs to the executors of the policies or programs. The certainty of this information should be guaranteed to support the success of the policies or programs. Hence, it is necessary that executors have deep understanding on the policies or program in order to be able to deliver important information for each of the client that will also support the success of certain policies or programs.

Resources in the Implementation of the Hajj Program Management in Mojokerto District. The most dominant resources that appears in this context is the human resources. Human resources in the Ministry of Religious Affairs office in Mojokerto has been considered lacking since the researcher found only 8 members who found it difficult to handle the complex jobs of the office This number is not appropriate compared to the number of the Hajj applicants who should be handled. Human resources are the major key to the success of the any implementation of programs or policies. The main resource refers to the staffs or employees in the office. It is important to note that staffs or employees do not simply guarantee positive contribution to the implementation of certain policies or programs. Therefore, more number of employees and staffs does not automatically guarantee good implementation of certain programs or policies. The human resources should also be equipped with good skill person of each individuals. However, it should be noticed that few number of staffs or employees may also create complex problems in the implementation of certain programs or policies. Moreover, the lack number of staffs or employees also triggers difficult problems related to the implementation of the Hajj program. In line with Mathis and Jackson (2006, p.3), human resources refer to a design of formal systems within an organization to guarantee that the potency of the human resources is effectively and efficiently explored to achieve the goals of the organization.

Dispositions in the Implementation of Hajj Program in Mojokerto District. Leaders of a bureaucracy are the persons in charge of an implementation of certain programs who work under the authority of the government. The implementation of the programs or policies is under their responsibility. More importantly, persons in charge do not have any influence toward their disposition. Government bureaucracy has some characteristics which differ from non-government institutions'. More importantly, the notion of dismissal in government-owned institution is considered as something shameful and disadvantageous. Therefore, the Ministry of Religious Affairs in Mojokerto regularly conducts workshops and education related to the implementation of the rule number 29 year 2015 to all of the staffs and employees in order to motivate them to work with high responsibility and commitment since their works are related to the implementation of Hajj program which is their routine works and they are wellexperienced in performing the job. Regarding the fact that the staffs of the Ministry of Religious Affairs Office in Mojokerto are the experts of the field, it can be assured that the implementation of the program runs well.

The Bureaucracy Structure of the Hajj Program Implementation in Mojokerto District. The bureaucracy is the executor of a certain policy. Either consciously or subconsciously, a bureaucracy creates a form of organization based on the collective agreement to solve social problems in this modern era. The bureaucracy is not only under the government's structure, but it can also be included in non-government organization even sometimes a system of a bureaucracy is created to run certain policies. According to Edwards III (Anggara, 2014, 
p.253), a bureaucracy structure refers to a work mechanism formed by the executor of a certain policy. It emphasizes on the importance of the standard operating system (SOP) which guides the flow of a work among the executors, moreover when the work relates more than one institutions. Edwards also highlighted that sometimes fragmentation is needed when the implementation of a certain policy requires complex programs and involves many institutions to achieve the goals. Within the implementation of the rule of the Ministry of Religious Affairs number 29 year 2014, the office of the Ministry of Religious Affairs in Mojokerto is expected to always work based on the predetermined SOP made by the leaders of Hajj program.

The tasks distribution is done by the head of the Hajj program in a flexible way even sometimes fragmentation on the structure of a bureaucracy of Hajj program occurs. For instance, within the committee of Hajj program, the head of the program is allowed to place certain staffs to handle certain work based on the quality of the human resource. Fortunately, the result of the system shows good implementation and meets the expectations.

Government's efforts to improve the quality service of the Hajj program implementation in Mojokerto District. The Hajj program service in Mojokerto is started from the socialization of the Hajj policies to make sure that the society receives clear information related to the procedure of Hajj program provided by the Ministry of Religious Affairs office in Mojokerto. The information contains detailed explanation related to the schedule and the enrollment procedure, Hajj fee (Biaya Penyelenggaraan Ibadah Haji/BPIH), Hajj manasik program and the Hajj event. One effort which has been done by the government to improve the quality of the Hajj service is in the form of a computer-integrated Hajj system (siskohat/sistem komputerisasi Haji terpadu). This system connects all of the data reaching up to the district level and it provides easiness and efficiency of Hajj service, enrollment management, and the payment of the Hajj fee, national Hajj quota management using a network and giving the certainty of the queue number, allowing the applicants to be treated fairly in getting their turn for Hajj. Hajj enrollment through the siskohat provides Hajj service throughout the year which can be monitored and controlled at anytime and in the real time. In addition, the one-stop Hajj service that is implemented by Hajj agencies in Mojokerto is the innovation proposed by the head of the Hajj program in Mojokerto district. This enhancement has successfully made Mojokerto district becomes the role model for other districts to implement similar Hajj system.

\section{CONCLUSION AND SUGGESTIONS}

Hajj applicants in Mojokerto were not yet able to independently take care of their own Hajj needs and they still needed the help of the Ministry of Religious Affairs of Mojokerto district to ensure that the Hajj program was done with more structured management to enhance better safety as expected by the law of the Republic of Indonesia Number 13 year 2008 and the law of the Ministry of Religious Affairs Number 29 year 2015.

The role of the government in the implementation of Hajj program is held by the Ministry of Religious Affairs office in Mojokerto which holds three main responsibilities including; service, consultation, and protection for Hajj applicants. The support from the government has given positive effect for the society related to their religious occasions, in which they will be given the certain time of their Hajj departure followed by deep explanation on their rights and obligations to receive protection as the citizen of Indonesia.

The implementation of Hajj program in Mojokerto has been well-conducted in accordance with the rule of the Ministry of Religious Affairs number 29 year 2015. Even though in this study, some problems were found, yet generally, the program has been optimally implemented. This was proven by the result of the data analysis done based on the principle of the public service. Therefore, the implementation of Hajj program performed by the Ministry of Religious Affairs office in Mojokerto has been done with good implementation.

It is suggested that the office provide call canter (free-toll) or customer care via social media or mass media for the socialization of the program. It is recommended that the office conduct events for the staffs and the employees such as exercises to boost up their physical condition that will support their performance in giving Hajj service. The government is also 
expected to eliminate the Hajj extra-fund which used to be stored in banks. It is also important to improve the participation of the Hajj applicants. In order to improve the quality of the Hajj service in Mojokerto, innovations are necessary to be created by the Ministry of Religious Affairs office in the form of one-stop Hajj service. The one-stop Hajj service refers to the merger of two institutions into one.

\section{REFERENCES}

1. Anggara,Sahya, 2014. KebijakanPublik, Bandung: CVPustakaSetia.

2. Edwards III, George C. 1980. Implementing Public Policy. Washinton:Congressional Quaerterly Inc.

3. Handayaningrat, Soewarno. 1992. Pengantar Studi Ilmu Administrasi dan

4. Manajemen. Jakarta: Cv Haji Masagung.

5. Mathis, L Robert. \& Jackson, H,John., 2006, Human Resource Management (Terjemahan Diana Angelica), Edisi Sepuluh; Jakarta: Salemba Empat.

6. Miles, Mathew B.A, Michael Huberman, Saldana. 2014. Analisis Data Kualitatif. Penerjemah Tjetjep Rohendi Rohidi. Jakarta: UI Press.

7. Winarno, Budi, 2012 .Kebijakan Publik Teori, Proses dan studi kasus, Jakarta: PT.Buku Seru. 